\title{
Analytical Comparison Between Spectrophotometer and Portable Glucometer for Measurement of Blood Glucose in Horse
}

Nanoshe Taye Jima

Addis Ababa University

Yoseph Cherinet Megerssa ( $\nabla$ yoseph.cherinet@aau.edu.et )

Addis Ababa University

\section{Research note}

Keywords: Glucometer, Glucose, Spectrophotometer

Posted Date: November 5th, 2019

DOI: https://doi.org/10.21203/rs.2.13351/v2

License: (c) (i) This work is licensed under a Creative Commons Attribution 4.0 International License.

Read Full License 
The authors have withdrawn the journal submission associated with this preprint and requested that the preprint also be withdrawn. 